\title{
An Approach for Teaching of National Languages and Cultures through ICT in Cameroon
}

\author{
Marcellin Nkenlifack ${ }^{1}$, Bethin Demsong ${ }^{2}$, A. Teko Domche ${ }^{3}$, Raoul Nangue ${ }^{2}$ \\ ${ }^{1}$ LAIA - IUTFV - University of Dschang, LIMMS - National Polytechnic \\ ${ }^{2}$ LAIA-IUTFV of Bandjoun - University of Dschang,Cameroon \\ ${ }^{3}$ Faculty of Letters - University of Dschang, Cameroon \\ Email: marcellin.nkenlifack@gmail.com
}

\begin{abstract}
This article describes the input of ICT to the modernization of teaching national languages and cultures in order to promote cultural diversity as well as dissemination of scientific knowledge through national languages. This will also reinforce the understanding capacities of the population. This project will serve as the guideline towards development of scientific knowledge and know-how. It presents numerous psychological, pedagogic, scientific and social advantages, among which there is a sensitization of our languages and cultures, the deployment of a platform in some schools, the training of teachers in using ICT in language teaching, the distribution selflearning aids, the development of a website for analysis and dissemination of cultural data, of conservation of linguistic and cultural heritage, and worthiness of pre-requisites and local predispositions towards the emergence and development of technology. It will contribute to make concrete the introduction of teaching national languages in the school curricula in Cameroon.
\end{abstract}

Keywords-Local Languages; Culture; ICT; Learning Platform; TICELaCuN; Management Tools.

\section{INTRODUCTION}

\section{A. State of the problem}

One can easily remark at this era of globalization and ICT that roughly $80 \%$ of Internet network contents are made in English language. This domination does favorise neither cultural diversity, nor local languages representation. One can therefore legitimately question the pertinence of this quasi mono cultural tool [1] [2] [3] when we consider that linguistic and cultural diversities represent one of the eleven fundamental principles geared towards edification of information society as prescribed by world summit on information society (SMSI/wsis). Thus, for the populations to have access to universal information, putting the contents in local languages becomes worth noting. This therefore perfectly justifies the interest of this project and the need of mobilization of researchers in the domain of science and technology to serve the essential purpose of Internet access in multilinguistic and multicultural contexts [1] [3] [4]. To achieve it, populations should first of all master their local languages and cultures, then after, couple them with communication tools thanks to ICT, in the way of going beyond speeches to solve this problem of mono cultural information model.

\section{B. Motivation for the project}

Introducing national languages and cultures in the school curricula and advantages that modernization of these languages gives are worth in psychological, pedagogic and social levels as it will be shown in the follow lines.

At Psychologically Level:

- From childhood, intellectual awareness and development rely on language and logical activities. This awareness and development that guide our thought portray our languages and cultures. They constitute the base for the construction of our own way of seen the world, paradigms and models of perception of ourselves and the universe.

- Individual performances and productivities are not only based on simple technical, financial or organizational mechanisms, but they also deeply depend on psychological inputs, on what is called a "personal equation" on people who conceive and realize projects. This equation is gradually elaborated with the mastery of our languages and cultures.

- Mastering our languages will enable to avoid linguistic and cultural uprooting of the youth. It will also make them to be proud of cultural heritage, to have a mutual respect through the understanding of their join heritage. This togetherness inevitably accelerates national and African integration.

- Promote nationals languages world wide

At Pedagogical Level:

- Teaching in our national languages will facilitate learning process and general dissemination of scientific knowledge (even in other languages). It will stimulate a high sense of initiative and creativity of the target population.

- Our languages play an irreplaceable role in dissemination of scientific and technologic knowledge.

- Teaching in national languages is not a rejection of the importance of other foreign languages used for a great dissemination of scientific discoveries at the era of globalization; instead, it will facilitate their learning capacities.

- Appearing as a mirror, the face and the soul of a people and its culture or as its mark of existence, a language when taught will enrich and over all world cultural diversity. 
- Using ICT will enable to make available dynamic soft modern tools useful in the learning and acquisition process.

At Social Level:

Teaching in national languages will help to:

- Avoid social and cultural uprooting of the target population in order to accelerate national and African integration;

- Possess dynamic soft modern tools useful to avoid the rapid erosion of our linguistic and cultural heritage;

- Initiate and develop a cooperative programme opened to the public. This programme should be focused on the analysis of cultural data ;

- Make Cameroon and African languages and cultures contribute to globalization

\section{Objectives:}

Our global objective is to promote linguistic and cultural diversity, to disseminate scientific discoveries and knowledge not only in official languages (French and English), but also in local languages. This combination will reinforce the general capacity of the target population.

This project is at the center of various national, sectorial, ministerial or thematic strategies of our country. The didactic dimension of it will lead to contribute to the consolidation of education as the fundamental mission of the country. In other words, it will greatly contribute to the reinforcement of the promotion of equality of chances to Cameroonian citizens with the use of new forms of teaching based on ICT. The operational phase of the display of this project will consist of introducing teaching local languages and cultures in official school curricula with the use of numerical, multimedia and interactive tools as means to teach languages, cultures, science and technology.

This project is geared towards a population made up of pupils, students, teachers, men in charge of promotion of cultures, linguists, researchers and neo-illiterates, to name a few.

Applying ICT in language teaching opens new ways to experimentation, to search new methods and tools that can favor learners' acquisition of language and intercultural skills.

When elaborating this project, we take into consideration a number of models focused on the nature of the partnership between schools, universities, civil society and the government. This models support the policy of innovation in education [5]. Matoussi corroborates by showing that in any didactic approach, a wrong choice of hypermedia teaching document to be used can impede the construction of learners' knowledge. In the same vein, Mattioli [7] presents a solution that can help learners from the University of Liège to follow a comprehensive distant training in foreign languages. This solution consists of making available to learners lectures prepared by lecturers and put in an e-learning platform. In the framework Leon-Grenoble tele-collaboration project, Tomé [8] gives priority to strategies and pedagogy practices leading to comprehension and oral productions, with the use of task and Web tools for learners' oral productions. A survey of needs, advantages and constraints (cf [19] of integration of ICT high schools teachers training colleges is presented considering national environment and context.

In this work, the techniques that we propose are applied gradually on concrete examples in order to put into evidence their operationalization.

This article tackles applied research and is divided into six sections.

In section I, we introduce the work; Section II discusses the context, section III describes the methodology; section IV presents the results; section $\mathrm{V}$ focuses on openings and extensions while section VI concludes.

Note: this article follows the development of experimental works on ICTE and new forms of teaching whose previous results are described in [9], [10], [11] [12] [13].

\section{CONTEXT}

From a survey on its context, it appears that is of great interest, be it at international, Cameroonian or Regional levels. An important number of legal texts have been issued to protect and promote our languages and cultures.

\section{A. International context}

\section{- At world level}

Texts and recommendations have been made at world level to portray the general determination to achieve the previously stated objective, some of them are:

- The June 9th, 1996 universal declaration on linguistics rights in Barcelona - Spain

- Recommendations of the International Organization of Francophonie (OIF) on teaching French and partner languages (African languages) and those of the consultative committee on national languages held in Paris from 17th to 19 December 2005.

- The Convention on protection and promotion of cultural diversity expressions held in Paris (France) on October 20, 2005.

\section{- At African level:}

The recommendations on teaching mother languages taken in 1961 during the first African conference on education held in Addis Abebas (Ethiopia).

\section{B. National context}

The national context is also very rich. Many texts signed definitely open the ways to the promotion of locale languages and their introduction in various training modules of the youth.

Cameroon ratified since 2008 (decree $\mathrm{N}^{\circ} 2008 / 178$ ) the UNESCO convention to safeguard immaterial cultural heritage as adopted in Paris on October17, 2003.

At the same time, the 1996 fundamental law, the 1998 law on new directives of education, the 2001 law on directives of higher education, the 2004 laws regulating rules to be applied on Councils and Regions, the 2005 and 2007 texts appointing national and regional inspectors in charge of teaching and 
promoting national languages and cultures, the 2008 texts creating the laboratory and Department in charge of teaching and promoting national languages and cultures in Higher Teachers Training College in Yaoundé and last but not the least the implementation on teaching national languages and cultures in five pilot government secondary schools, namely: Government High School Leclerc in Yaounde in the Center Region, Government High School Akwa in Douala in the Littoral Region, Government High School Bafang in the West Region, Government High School Njinikom in the North West Region and Government High School Garoua in the North Region.

This new philosophy led to the recruitment in 2009 of 40 students in the Department in charge of teaching and promoting national languages and cultures in Higher Teachers Training College in Yaoundé.

Many teams of actors and researchers are now mobilized to put into practice these new directives. It is worth noting the contribution of a number of partners to codify and standardize our languages in order to make them be used adequately in teaching and literacy programmes. They are: SIL (Société International de Linguistique), CABTAL (Cameroon Association for Bible Translation and Literacy), ANACLAC (Association Nationale des Comités de Langues Camerounaises), language committees, Universities.

\section{Regional Context}

« Bamilékés » and «Bamoun » cultures are classified among the most original ones in Cameroon and Africa. About six languages committees are active in this vicinity. They are:

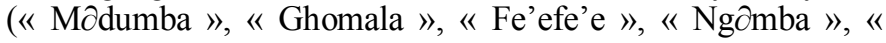
Ngiembon », « Yemba »).

A number of languages in our country are not more only spoken nut already written since a century for some. To illustrate it, we can point out that "Fe'efe'e » is written since 1928, that is already for 80 years. Many scientific works have been carried on in our languages and didactic materials have been produced to teach both in primary and secondary schools are available for " Fe'efe'e », " Ghomala » and " Modumba » languages. Some of them are effectively taught in some secondary schools since 1966. Many teachers have been trained both in their language and on efficient pedagogic methods. They could be more efficient if they master how to use ICT to avoid the destruction of their linguistic and cultural heritage.

\section{METHODOLOGY}

\section{A. Process}

Sensitization is worth in our process of implementation this philosophy. This sensitization is very important before starting the training phase of the target population on the interest of ICT in the acquisition and transmission of knowledge through the mastery of local languages and cultures.

We are going to give priority to technical, ergonomic and pedagogic aspects, to hypermedia documents (on line and/or off line) in training teachers. This should be based on learning in situation or in case study. It will lead young teachers to experience these pedagogies in situ using ICT in a transversal project during the training sessions. This will be done via a training platform which provides a great chance of manipulation in managing the time allotted for training.

At the turning point of this process, there is the TICELaCuN (in French - "TIC pour l'Enseignement des Langues et Cultures Nationales") multimedia platform. The sides are built up with steps and modules. They cover:

- Knowledge acquisition modules from experts

- Knowledge structured into training scenario

- Feedback of knowledge acquisition interface to learners

- Evaluation module of learners' progress

- Production of self training material such as written papers, CD, DVD to be used on the platform

- Display of the platform in schools and communities

- Inventory, test and integration of existing solutions, of other tools and softwares... (SIL resources) after having divided them into lessons

- Development and putting on line of a dynamic Internet site available to the population. It should be meant to promote and develop national languages and cultures

A set of activities directed towards real life situations are given to learners during the learning process. He can consult whenever needed a glossary of terms related to the situation considered in relation to the cultural dimension of the chosen language to be taught.

Each module is backed by interactive and productive exercises (oral or written). These exercises are aimed at evaluation and the learner can check his level of acquisition of the competences targeted by the session.

By diversifying the modes of presentation of information, hyper Medias offer much for documentary research. However, their usage can have side effects if it does not respect the previously stated pedagogic and didactic strategies [6].

We have started a number of specific projects first of all by gathering the pluri-disciplinary researchers needed into groups. Our best wish is that the various results we arrived at should immediately be tested and got down to work gradually on the platform developed for the purpose. We can name a few:

- Specific keyboards for phones computers, TV panel controllers in national languages. [18]

- Text editors in local languages with a use of orthographic correctors

- Generation of special characters (in local languages) non UNICODE and development of pilots such as Linux, Windows for control (virtual keyboard) and display of characters on a screen when editing

- Translators (orthography, grammar, phonology) and numerical dictionaries in local languages

- Modules for vocal recognition (to teach and learn pronunciation) 
- Didactic workshops on vocal recognition

With the various research programmes that go with this project, all the modules realized, specially the training platform, are updated in a dynamic way to integrate the results obtained or acquired from people initiated on.

It is form his reason that a team is now working at integrating m-learning techniques in the platform [4], other team is working on other aspects.

\section{B. Operational Components of the Project}

A survey has proved that this project scrupulously respects a well defined logic. Table 1 indicates the various components of this project, the results expected and its measurement indicators while table 2 presents its physical display programme scheduled for five years.

\section{Actors of the System}

This system is made up of five different groups of actors. Figure 1 illustrates the role play of each category of actors in Cameroon context. It has already been hinted in [1].

Operationally, teachers and learners should work in a multimedia room equipped with computers connected to an Internet or a local network. These computers should be equipped with tools such as audio recorders, numerical photo device, video, microphones and earphones.

TABLE I. COMPONENTS OF THE PROJECT

\begin{tabular}{|c|c|c|c|}
\hline $\mathrm{N}^{\circ}$ & Components & Results & Measurement Indicators \\
\hline 1 & $\begin{array}{l}\text { Institutional and structural support } \\
\text { Putting in place and rehabilitation of } \\
\text { equipments } \\
\text { Training of trainers and recruited network } \\
\text { administrators }\end{array}$ & $\begin{array}{l}\text { - multimedia centres built or } \\
\text { rehabilitated } \\
\text {-training of personnel and } \\
\text { administrators }\end{array}$ & $\begin{array}{c}\text { - Number of multimedia centers built or } \\
\text { rehabilitated } \\
\text { - Number of trainers trained } \\
\text { - Number of platform administrators recruited } \\
\text { or trained }\end{array}$ \\
\hline 2 & $\begin{array}{c}\text { Development of the platform for } \\
\text { modernization of languages and cultures } \\
\text { teaching }\end{array}$ & $\begin{array}{l}\text { - operational platform } \\
\text { - opening towards other } \\
\text { modules }\end{array}$ & $\begin{array}{c}\text { - operationality and users-friendliness platform } \\
\text { - Number of applicative layers offered } \\
\text { - description of interactions with other research } \\
\text { modules }\end{array}$ \\
\hline 3 & $\begin{array}{l}\text { Display, creation and enrichment of } \\
\text { permanent contents }\end{array}$ & $\begin{array}{l}\text { Scenarios and basic } \\
\text { knowledge created }\end{array}$ & $\begin{array}{c}\text { - Number of schools } \\
\text { - Number and qualities of documents and media } \\
\text { - Number of scenarii } \\
\text { - Number of evaluations } \\
\text { - Number of languages } \\
\text { - Cultural heritage } \\
\end{array}$ \\
\hline 4 & $\begin{array}{c}\text { Science of education and technology research } \\
\text { projects applied to ICT, local languages and } \\
\text { cultures }\end{array}$ & $\begin{array}{l}\text { Research modules to facilitate } \\
\text { languages teaching }\end{array}$ & $\begin{array}{l}\text { - Number of research projects tested and } \\
\text { appreciated positively } \\
\text { - availability of the collaboration platform }\end{array}$ \\
\hline 5 & $\begin{array}{l}\text { Management of the project, of local } \\
\text { personnel and of evaluation missions } \\
\text { Consultations }\end{array}$ & $\begin{array}{c}\text { - dissemination of } \\
\text { information } \\
\text { Control of resources } \\
\text { management } \\
\text { Missions meant for actors } \\
\text { Control and evaluation } \\
\text { structures } \\
\end{array}$ & $\begin{array}{l}\text { - distribution of budgetary package } \\
\text { - Assessment of activities } \\
\text { - missions specified and texts broadcasted } \\
\text { - number of technical controls carried on }\end{array}$ \\
\hline
\end{tabular}

TABLE II. PHYSICAL DISPLAY PROGRAMME OF THE PROJECT

\begin{tabular}{|c|c|c|c|c|c|}
\hline $\begin{array}{c}\text { Phases \& tasks } \\
\text { to achieve }\end{array}$ & 2010 & 2011 & 2012 & 2013 & 2014 \\
\hline Tasks/works & $\begin{array}{l}\text { Analysis of the } \\
\text { context and } \\
\text { institutional } \\
\text { framework }\end{array}$ & $\begin{array}{c}\text { A survey of } \\
\text { organizational and } \\
\text { technical solutions } \\
\text { Installation of basic } \\
\text { Equipment }\end{array}$ & $\begin{array}{l}\text { Display, equipment } \\
\text { and solutions } \\
\text { finding, beginning of } \\
\text { experimentation } \\
\text { Training }\end{array}$ & $\begin{array}{c}\text { Installation of } \\
\text { equipments } \\
\text { Experimentation } \\
\text { Assessment and } \\
\text { preparation of a } \\
\text { generalization plan }\end{array}$ & $\begin{array}{l}\text { Installation of } \\
\text { equipments } \\
\text { Progressive } \\
\text { Generalization and } \\
\text { follow up of training } \\
\text { sessions }\end{array}$ \\
\hline Equipment & RAS & $\begin{array}{c}\text { Basic equipment for } \\
\text { development } \\
\text { Passive equipments of } \\
\text { pilot sites }\end{array}$ & $\begin{array}{c}\text { Active equipment } \\
\text { and Internet } \\
\text { connection of pilot } \\
\text { sites }\end{array}$ & $\begin{array}{c}\text { Passive equipment of } \\
\text { other sites }\end{array}$ & $\begin{array}{c}\text { Active equipment and } \\
\text { Internet connection of } \\
\text { other sites }\end{array}$ \\
\hline $\begin{array}{c}\text { Consultation } \\
\text { Services and } \\
\text { Survey }\end{array}$ & $\begin{array}{l}\text { Survey on context } \\
\text { and institutional } \\
\text { framework }\end{array}$ & $\begin{array}{c}\text { Prior survey of technical } \\
\text { and organizational } \\
\text { solutions }\end{array}$ & $\begin{array}{c}\text { Research and } \\
\text { realization of basic } \\
\text { scenarios and } \\
\text { modules }\end{array}$ & $\begin{array}{l}\text { Validation and feedback } \\
\text { continuation of research } \\
\text { in other modules }\end{array}$ & $\begin{array}{c}\text { Continuation of } \\
\text { development of } \\
\text { complementary } \\
\text { modules }\end{array}$ \\
\hline
\end{tabular}




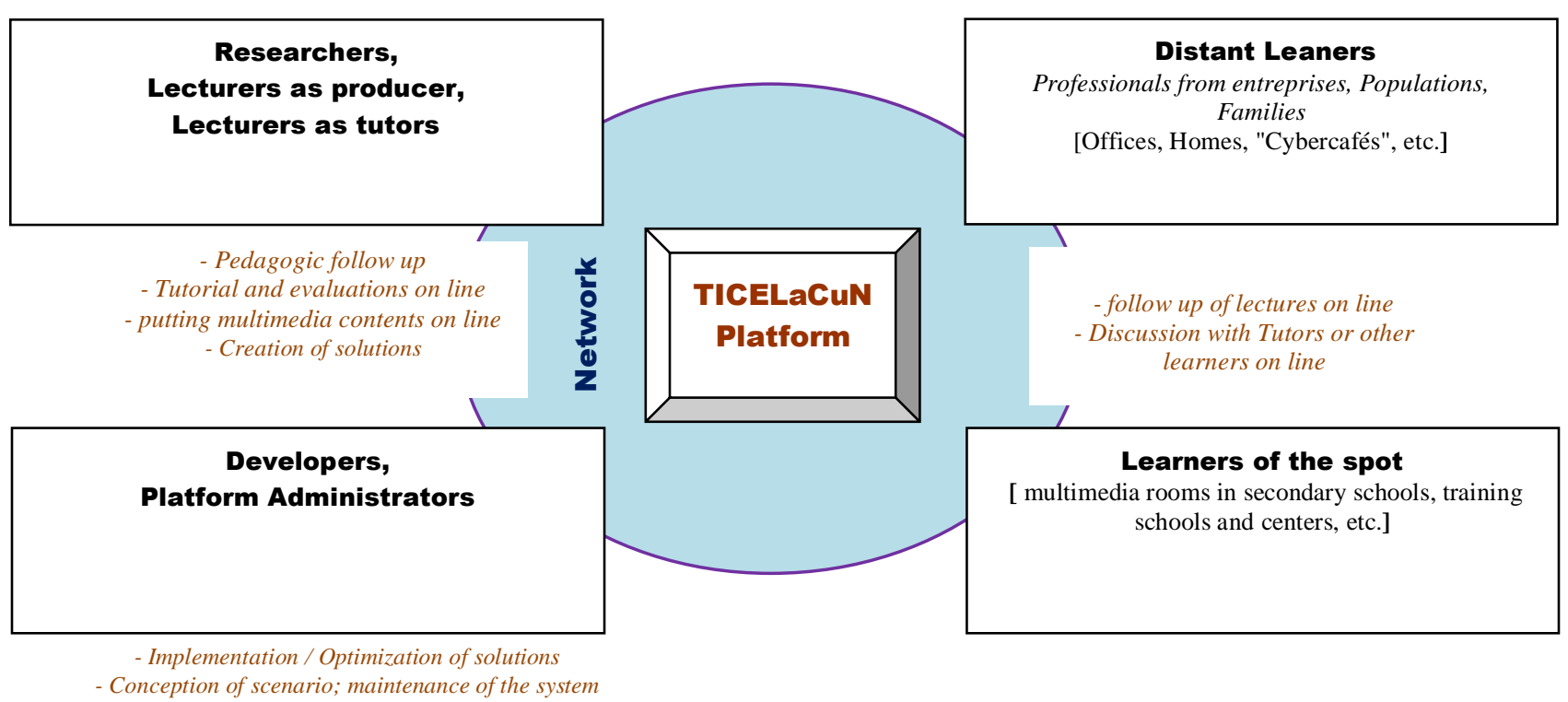

Figure 1. Various actors of the system

\section{Technologies used and global architecture}

We have based our research on a set of techniques and tools offered by New technologies and already discussed by many researchers in "E-learning" and "Web Services" domains [13] [14] [15] [3] [11]. We are going to put into action a set of applications integrated in our TICELaCuN platform. The online teaching - learning environment combines the two categories of tools usually found in ICT: asynchronous and synchronous tools.

In the following lines, we present the main technical components of our architecture with some guarantees it gives:

- Web access to available information such as lectures backups, directed work forms, Labs, charts, video

- Access to an important space of collaboration, share of ideas, classical communication integrated in our "numerical campus"

- A shared working platform; announcement space, classical or instantaneous messaging

Our strategy is basically focused on implementation and display of application thanks to free softwares such as: Backup)

- A secured Linux server (level of access, fireWall,

- Development and Communication tools such as ApacheMySQL-PHP, LDAP-SMB, WebMail-IMAP-SMTP

- Resources stocked on the platform based on Claroline kernel with its code deeply reviewed to adapt it to our need. These adjustments include evaluation modules, multiple connection control on the platform, chat, harmonization of authentication from LDAP (Lightweight Directory Access Protocol) in charge of centralization of resources input, the inter-operability and portability of the system. The platform of resources hosts various backups at various formats.
- A FilesServer that safely secures the stocking of directory of tutors and learners

Figure 2 presents the client-server architecture. It is of the « multi-tiers » type inspired from [11] [16]. The first layer is the interface, the second is the applicative layer and the third is the data stocking layer.

Our platform based on a basic technical kernel is dynamic. The description of this article geared towards computer science will not be taken in details; readers can report to [17] [11]. The TICELaCuN system is made up of a set of subsystems presented as follow:

- The «Distant Learning System »: it offers a resources library to the learners registered such as multimedia backups, exercises and other didactic tools.

- The « Learning Management System » : It enables learners to register on line, to consult their marks on line, to submit and follow up the development of their petitions on time, just to list a few.

- The «Mail \& SMS system » manages communication data between intervening actors. Messages are distributed automatically. The documents run by SIGES are equally transmitted by e-mail. The SMS module manages automatically alerts transmitted to tutors and learners (eg: submission of new documents, etc.).

- The global system users can use one account to log to every service offered by TICELaCuN. This is possible thanks to Universal LDAP directory.

Evidently, the access and communications between various modules and services make use of software buses. 


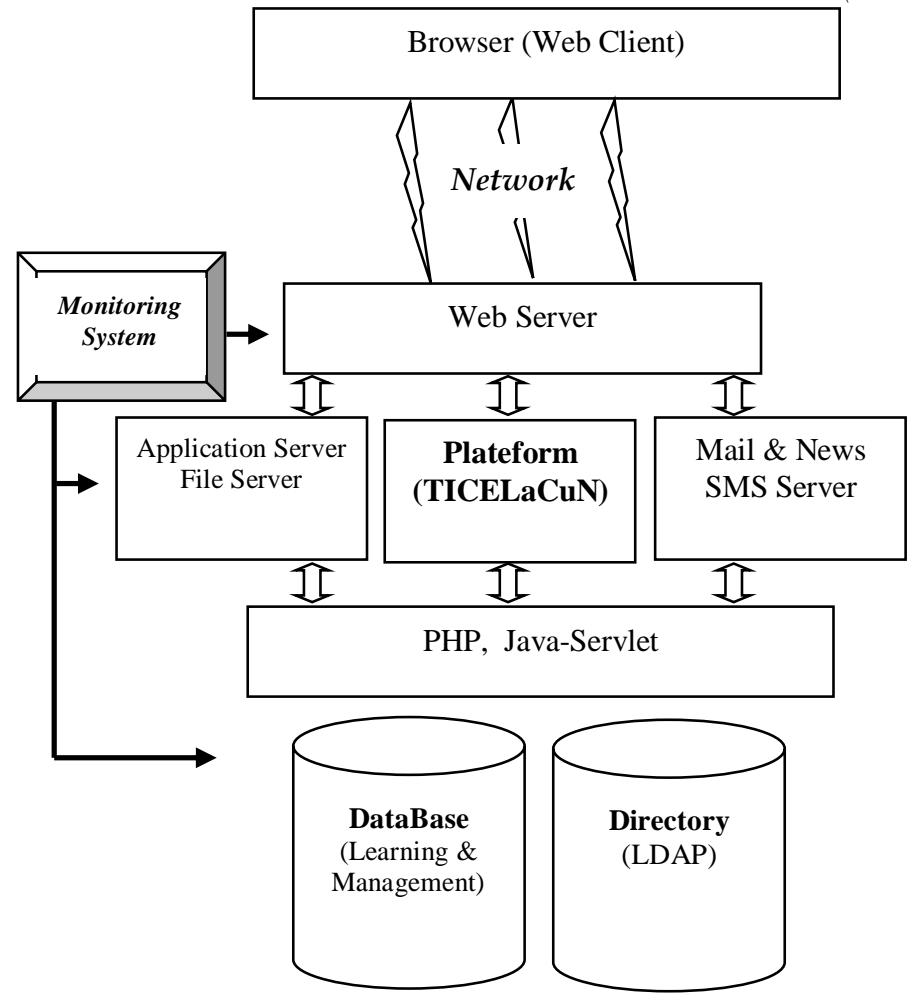

Figure 2. Architecture of the system

\section{RESUlTS AND CONTRIBUTIONS OF THE PROJECT}

\section{A. State of fulfilment}

The TICELaCuN project is been set gradually and the setting up can already been observed. Terms of reference and various surveys have already been realized. They include:

- A survey on its impact

- Technical survey

- A survey on the risks

- A survey on the economy

- A survey and financial programming of works

As the real level of execution is concerned, we can name:

- The planning of all the tasks done

- Teams of correspondents at work

- Operational teams in activities

- The teams of researchers are been formed and are been enlarged for, it is an important project embodying a variety of competences and human resources from various disciplinary domains.

Actually, a platform is been experienced and will permit to:

- create an online dictionary to learn a given language

- create an automatic translator of words in French and any chosen language

This project will enable to consolidate or to contribute to a better value of the requisites and predispositions in local languages to the development of technology.

\section{B. Exploitation of results}

This project of national scale will offer a framework for exchanges and free cooperation between specialists in local languages, sociologists, linguists, men in charge of cultures, researchers. It will permit to extend training to a larger number of people. It also stands as a solution to the lack of teachers in schools. Moreover, a lecturer could give his lectures independently to his/her geographical position.

The technology put in place will ease the updating of lectures' contents with a wider range of openings to exploitation.

We shall gradually sensitize the possible distant population via media and leaflets on the need to initiate days of national languages in schools and universities.

The project is backed by a dynamic web site for numerical archiving and preservation of national linguistic and cultural heritage. The contributions from the population are collected through the dynamic web site. Those of experts and correspondents pass through the platform displayed after seminar to train trainers.

The first modules of the platform are been experienced. Some extracts of them can be illustrated in [17] as presented afterwards. In figure 3, we have the page of translation from French to «ghomálá » (a local language spoken in the West Region of Cameroon) and figure 4 presents a page of learning the alphabet of the same language.

Table 3 presents the expected outputs and products of the first phase of the project. They are quantified in relation to the target population (men, women, young people and others) and their quantity. 


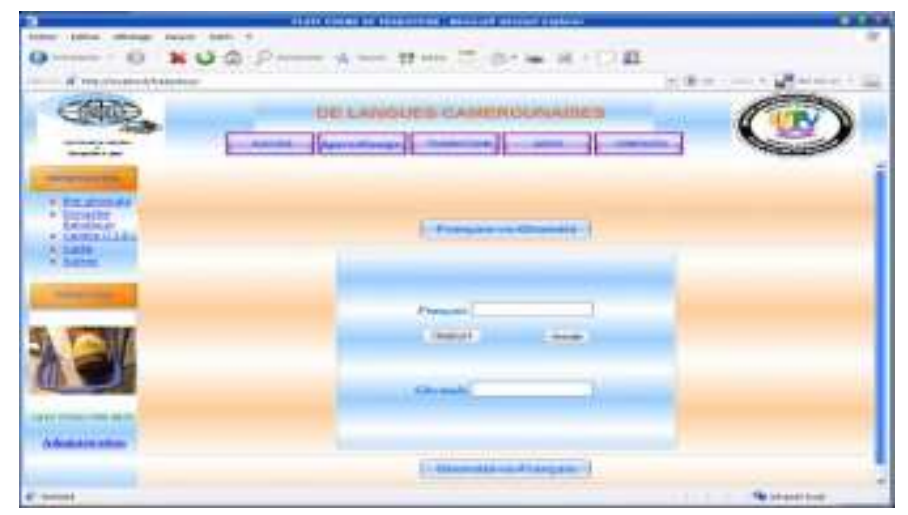

Figure 3. A translation page from French to "ghomálá" (a local language spoken in the West Region of Cameroon)

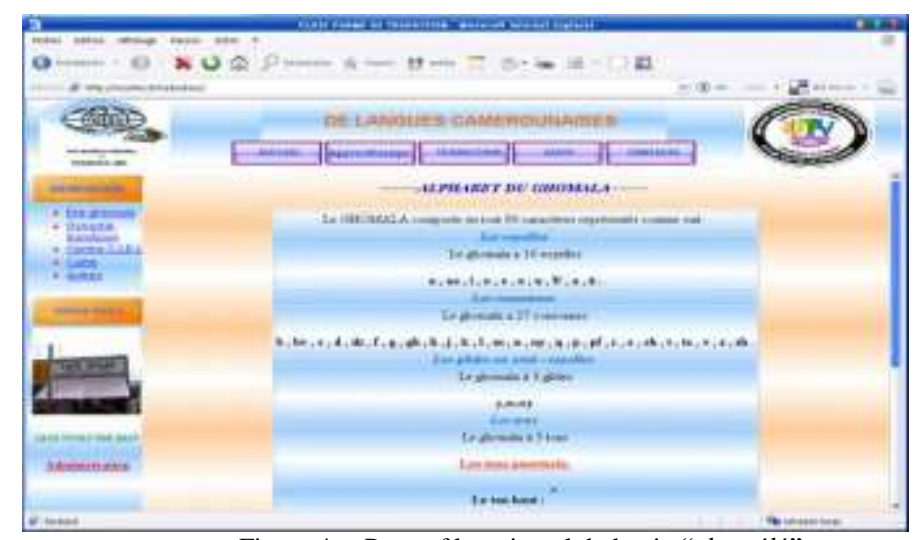

Figure 4. Page of learning alphabet in "ghomálá"

TABLE III. EXPECTED OUTCOMES AND PRODUCTS AWAITED FOR PHASE 1 OF THE PROJECT

\begin{tabular}{|c|c|c|c|c|c|c|}
\hline \multirow{2}{*}{\multicolumn{2}{|c|}{$\begin{array}{c}\text { Major outcomes } \\
\text { (goods and services) }\end{array}$}} & \multirow[t]{2}{*}{ Quantity or values } & \multicolumn{4}{|c|}{ Target beneficiaries } \\
\hline & & & men & women & Young people & Others \\
\hline - & Training of trainers and leaders & 150 & 50 & 50 & 50 & \\
\hline$\bullet$ & $\begin{array}{l}\text { Training of platform } \\
\text { administrators }\end{array}$ & 100 & 25 & 25 & 50 & \\
\hline$\bullet$ & $\begin{array}{l}\text { Production and distribution of } \\
\text { CDROMs and DVD }\end{array}$ & 500000 & 150000 & 150000 & 200000 & All regions \\
\hline & $\begin{array}{l}\text { Display of TICELaCuN (TIC } \\
\text { pour l'Enseignement des } \\
\text { Langues et Cultures nationales) } \\
\text { Platform }\end{array}$ & $\begin{array}{l}100 \text { schools (government high } \\
\text { schools and colleges...) }\end{array}$ & $\begin{array}{c}\text { Total Access to } \\
\text { schools }\end{array}$ & $\begin{array}{l}\text { Total } \\
\text { Access to } \\
\text { schools }\end{array}$ & $\begin{array}{l}\text { Total Access to } \\
\text { schools }\end{array}$ & $\begin{array}{l}10 \text { per region } \\
\text { Schools, } \\
\text { professionals, } \\
\text { research institutions } \\
\text { and homes }\end{array}$ \\
\hline & $\begin{array}{l}\text { Analysis and broadcasting on } \\
\text { official site of numerical } \\
\text { archiving and preservation of } \\
\text { national cultural heritage }\end{array}$ & $\begin{array}{l}\text { Accessible server via Internet } \\
\text { nd Intranets put in place }\end{array}$ & unlimited & unlimited & unlimited & The entire population \\
\hline & $\begin{array}{l}\text { Support of research through } \\
\text { mobilization of researchers }\end{array}$ & $\begin{array}{l}\text { Many teams planned at various } \\
\text { levels of the project }\end{array}$ & $\begin{array}{l}30 \text { researchers } \\
\text { of different } \\
\text { domains }\end{array}$ & $\begin{array}{c}15 \\
\text { researchers } \\
\text { of different } \\
\text { domains }\end{array}$ & $\begin{array}{l}40 \text { developers } \\
\text { And integrators }\end{array}$ & $\begin{array}{l}1 \text { team to pilot and } \\
\text { tens of correspondents } \\
\text { and consultants }\end{array}$ \\
\hline & $\begin{array}{l}\text { Operationnalization of many } \\
\text { national languages }\end{array}$ & $\begin{array}{c}\text { - phase } 1: 3 \text { languages } \\
\text { - phase } 2: \text { more than } 10 \\
\text { languages }\end{array}$ & & & & $\begin{array}{c}\text { An average of at least } \\
\text { one language per } \\
\text { Region }\end{array}$ \\
\hline
\end{tabular}




\section{Projections : Display in schools}

The projections planned for the progressive putting in place of the project in Cameroon in Regional Cameroon are presented in figure 5 .

From the following chart, it is clearly seen that to cover the entire nation, it needs about five years.

\begin{tabular}{||c|l|l|l|l|}
\hline & & & & \\
\hline & & & Potential=40 & Confirmed=120 \\
\hline & & Potential=40 & Confirmed=70 & \\
\hline & Potential=30 & Confirmed=40 & & \\
\hline Potential = 10 & Confirmed=10 & & & \\
\hline Experimentation & & & & \\
\hline Sept. 2011 & Sept. 2012 & Sept. 2013 & Sept. 2014 & Sept. 2015 \\
\hline
\end{tabular}

Figure 5. Projections of display of the system in the nation

\section{ANALYSIS OF IMPACT, OPENINGS AND PERSPECTIVES}

Gradually as the project evolves, it becomes clear that we are managing to use systematically ICT to master our languages in training schools, research and homes. Standardization and harmonization of language teaching (official curricula) increases chances of success of students in official exams for, examination questions are common in the nation.

The majority of students in high schools and colleges registered in the platform are particularly motivated by their usage of new forms of teaching. They find these forms passionate thanks to the availability of operational pedagogic tools (teacher's guiding textbooks, Labs, individual training exercises, exams) and improvement of contents constantly updated.

Thus, we have succeeded a betting of mobilization of researchers (Doctorates and Masters) for the development of various applications.

We have presented the operational and technical components of the project, the carry on demonstrations [11] [12] [13] during which many opportunities were offered. Hence, from this project, the reflexion can be extended by researchers to:

- A profound survey of the influence of a language on development of science and technology;

- A thorough exploration of Internet and let its usage serve the development and interests of users while insuring the promotion of linguistic and cultural diversity;

- Analysis of the contribution of Internet to the reduction of gap between rich and poor countries, notably the numeral dissemination of technology and scientific information in local languages;

- Analysis of conditions of economical efficiency and productivity of a multilingual Internet;

- Study how to make Internet affordable to all; how to overcome problems of equipments and make Internet affordable to people more or less literate;

- Development of new solutions and possibilities to create interfaces to give access to Internet to people who do not know how to use at least one of the major languages used in numerical network.

At a typical technical level, when we consider the technologies used or planned, the project opens new perspectives, with the possibilities of generalization of the usage of ICT through the development of supplementary management tools in other domains such as health, agriculture, virtual library, academics, etc.

\section{CONCLUSION}

A language is the mirror, the face, the soul of the people and its culture, its mark of the existence. From our experiences, language teachers (as from their testimony) have a real framework required to efficiently train the learners by adapting their lectures to the needs and interests of learners in the country.

Though computers play a prominent role in on line teaching and learning process, the role of teachers cannot be minimized. We do not neglect the worries in [7]. They sustain the fear of computers and support the idea that computers dehumanize at consequently it discourages some people. But the general tendency of actors and target populations is a progressive motivation, thanks to positive contributions of the new forms of teaching-learning methods which make the learning process easy and exchanges as well as diversity among individuals.

This project offers important opportunities to the country, when considering its outcome as:

- Promotion of the development at social, human, economic and technological levels;

- Development through ICT and new forms of learning and teaching methods;

- Development of our capacities necessary to ease our integration on the global village while reducing the gaps between the rich and poor countries.

An actual asset on this project concerns free softwares. They provide:

- A better independence (technical, financial aspects, ...

- More ease in the display

- More possibilities to update (GPL) the tools used

- More facilities of maintenance

The project will permit to overcome a number of challenges in future. It will provide a sustainable development with our languages and cultures through ICT.

ACKNOWLEDGMENT 
This project has been conceived thanks to the expertise and support, be it direct or indirect of a number of partners and contribution of many structures already associated or to be associated to the project, notably:

- AUF (Agence Universitaire de la Francophonie),

- PNUD (Programme des Nations Unies pour le Développement),

- MINRESI (Ministère de la Recherche Scientifique et Technique)

- MINESUP (Ministère de l'Enseignement Supérieur du Cameroun)

- MINESEC (Ministère des Enseignements Secondaires) à travers ses Délégations Régionales et Départementales

- MINEDUB (Ministère de l'Education de Base)

- MINCULTURE (Ministère de la culture)

- University of Dschang / IUTFV Bandjoun (Internet Academy)

- Research Laboratories : LAIA (IUTFV), LIRIMA, LETS, LIMSS (National Polytechnic)

- Other Partners having exchanged with us during Seminars and Workshops: SIL, CABTAL, ANACLAC, CERDOLTOLA.

\section{REFERENCES}

[1] Essono, L. (2008), « Enseignement des langues locales par Internet : Le Cameroun relève le défi », Revue en ligne Thot Cursus le monde de la formation à distance, mise à jour le vendredi 12 décembre 2008, http://www.cursus.edu/?division $=19 \&$ module $=$ document \&uid $=66743 \& 0$ $=$

[2] Onoholio S. (2009), « Lobbying Ingénieurs polytechniciens Mobilisation pour l'accès des langues africaines à Internet », Journal Le Messager, 7 $12-2009$

[3] Drissi M. and Talbi M. (2009), "Dispositif de la formation à distance pour préparer les étudiants universitaires marocains à suivre des cours scientifiques en français - FOSEL (français sur objectifs spécifiques en ligne)", Revue africaine de didactique des sciences et des mathématiques, Numéro 4, 15 décembre 2009 : http://www.radisma.infodocument.php?id=687.

[4] Lapalme, G. Brun, C. Dymetman, M. (2003). MDA-XML : une expérience de rédaction contrôlée multilingue basée sur XML, TALN 2003, Batz-sur-Mer, 11-14 juin 2003.

[5] Laferrière T., Montane M., Gros B., Alvarez I., Bernaus M., Breuleux A., Allaire S., Hamel C., Lamon M. (2010), « Partenariats pour la coélaboration de connaissances : un modèle en émergence », Canadian Journal of Learning and Technology, V36(1) Fall / automne, 2010

[6] Matoussi F., Simonneaux L. (2009), Didactique et Technologies de l'Information et de la Communication, ISDM N ${ }^{\circ} 39$, TICE Méditerranée Milano 2009, http://isdm.univ-tln.fr

[7] Mattioli-Thonard A. (2009), « L’Enseignement Télématique des Langues: vers une bonne Distance », ISDM N³9, TICE Méditerranée Milano 2009, 695, http://isdm.univ-tln.fr

[8] Tomé M. (2009), « Compétences orales et outils de communication Web dans un projet de télécollaboration pour l'apprentissage du français langue étrangère », Journal of Distance Education, vol. 23, no. 1, 107126, 2009

[9] Marcellin Nkenlifack, Raoul Nangue, Bethin Demsong and Victor Kuate Fotso, ICT for Education: A Platform for Modernization of computer science teaching methods in secondary and high schools in Cameroon, International Journal of Advanced Computer Science and Applications, Vol. 2, No. 4, 2011

[10] Marcellin Nkenlifack, Bethin Demsong and Raoul Nangue, Identité Numérique et Education : Enseignement des Langues Camerounaises grâce aux TIC, ISDM (Information Sciences for Decision Making), $\mathrm{N}^{\circ}$ 41, 712, March 2011, http://isdm.univ-tln.fr

[11] Nkenlifack M., Nangue R., Tchokomakoua M. (2009), "Projet TICLAC : TIC pour la Modernisation de l'Enseignement des Langues et Cultures nationales dans les établissements, Conférence internationale : ASAP 2009 sur la "Diversité culturelle et Internet multilingue en Afrique", 2 au 5 décembre 2009, Hôtel Hilton, Yaoundé-Cameroun

[12] Nkenlifack M., Nangue R., Noulamo T. and Kwonche A. (2009), "Les TICE au service de la Formation Ouverte à Distance à l'Université de Dschang : Implémentation de SIEL (Système Intégré d'Enseignement en Ligne basé sur Internet)", Journal Langue et Communication, $\mathrm{N}^{\circ} 07$ novembre 2009, Revue scientifique internationale de recherche multidisciplinaire, ISSN 1560-3407

[13] Fogue M. and Nkenlifack M. (2006), "Formation Ouverte à Distance : Nouvelle façon d'apprendre et d'enseigner, ETUDE DE CAS SUR LA DIVERSIFICATION DE L'ENSEIGNEMENT SUPÉRIEUR ET L'ADAPTATION AU MARCHÉ", Conf. Int., Thème "L'enseignement Supérieur au coeur des Stratégies de Développement en Afrique Francophone. Mieux Comprendre les Clefs du Succès", 13-15 Juin 2006, Ouagadougou, Burkina Faso http://siteresources.worldbank.org/EDUCATION/Resources/278200$1121703274255 / 1439264$ 1137083592502/Presentation_IUT_Dschang.ppt

[14] Talla N., Tonye E., Dipanda A. and Ewoussoua L. (2010), "A model of Distance Learning of Technologies for Developing countries: Case of the Master (M2) in Telecommunications at the National Advanced School of Engineering in Cameroon", 10th African Conference on Research in Computer Science and Applied Mathematics CARI'2010, Côte d'Ivoire, Yamoussoukro, October 18 - 21, 2010

[15] Meyong, C. (2010). Appropriation des innovations dans les écoles normales supérieures : une étude des besoins, des avantages et contraintes de l'intégration des TIC : Appropriation of the innovations in the Ecoles Normales Supérieures: a study of needs, advantages and constraints of the integration of ICT. frantice.net, Numéro 1 - juillet 2010. Récupéré du site de la revue : http://www.frantice.netdocument.php?id=125. ISSN 2110-5324

[16] Koum G., Yekel A., Tampolla S. and Sanbong T. (2005), "Vocal Interaction in Web User Interface involving natural Language Processing", in Akono A., Tonye E., Dipanda A., Kokou Y. (ed.), Proc. Int. Conf. On Signal \& Image Technology and Internet Based Systems, IEEE SITIS'2005, Yaounde, Cameroon, ISBN 2-9525435-0.

[17] Mangui, A. Domche, S. (2008). Réalisation et Mise sur pied d'une plateforme web de traduction de langues camerounaises, Mémoire de fin d'études de DUT Informatique de Gestion, IUT FV de l'Université de Dschang, Cameroun, 2008.

[18] Wishart J., McFarlane A. and Ramsden A. (2005), "Using Personal Digital Assistants (PDAs) with Internet Access to Support Initial Teacher Training in the UK", mLearn 2005, 4th World conference on mLearning, Cape Town, South Africa, 25 -28 October 2005. Available: http://www.mlearn.org.za/CD/papers/Wishart.pdf

[19] Mvoto C. (2010), "Appropriation des innovations dans les écoles normales supérieures : une étude des besoins, des avantages et contraintes de l'intégration des TIC", frantice.net, Numéro 1 - juillet 2010. Récupéré du site de la revue http://www.frantice.netdocument.php?id=125. ISSN 2110-5324 


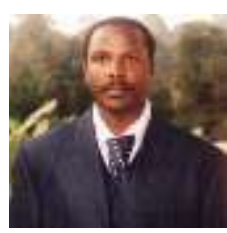

\section{AUTHORS PROFILE}

Dr. Marcellin NKENLIFACK is the Head of Computer Science Department at Fotso Victor University Institute of Technology, University of Dschang, and an Associate Professor. He is a holder of a M.A. Degrees in Computer Science and a Ph.D. in Computer Engineering and Control from National Polytechnic Institute, University of Yaounde I. He had been a visiting researcher at "Institut Scientifique et Polytechnique" Galilée "Université de Paris 13" (2001), SUPELEC - Rennes - France (2003) and "Université Check Anta Diop" - Dakar, Senegal (2009). He has published more than 20 papers in reputed International journals and Conferences in the field of Software Engineering, Computer Applications in Industry and Engineering, Object oriented Modeling and Simulation, Meta-modeling, UML, Hybrid Control Systems, Distributed Control, Computer in Education, E-learning. He has been awarded a Lecturer's award for 2003-2008 period for exceptional contributions towards developing e-learning at University of Dschang. $\mathrm{He}$ is an Editorial Board Member / Associate Editor / Reviewer of many internationals journals and conferences.

Bethin Demsong is a Head of Service in charge of General Affairs, IUT Fotso Victor of the University of Dschang, Cameroon, studying with the cycle of Master in Science of Language at the University of Dschang,Cameroon.

A. Teko Domche is Lectrurer in Faculty of Letters, University of Dschang. He is co-autors of more than ten scientific papers in various journals.

Raoul Calvain Nangue is teaching and researching at Laboratory LAIA of the IUTFV of the University of Dschang. It is also a Doctorate in the "Department of Information and Communication Technology, School of ICT, Nelson Mandela Metropolitan University" in South Africa. 